Article

\title{
Sulfur Species, Bonding Environment, and Metal Mobilization in Mining-Impacted Lake Sediments: Column Experiments Replicating Seasonal Anoxia and Deposition of Algal Detritus
}

\author{
Jeff B. Langman ${ }^{1, * \mathbb{D}}$, Jaabir Duunya $\mathrm{Ali}^{2}{ }^{2}$, Andrew W. Child ${ }^{3} \mathbb{D}$, Frank M. Wilhelm ${ }^{4} \mathbb{D}$ and \\ James G. Moberly ${ }^{3}$ (D) \\ 1 Department of Geological Sciences, University of Idaho, Moscow, ID 83844, USA \\ 2 Faculty of Geosciences, Geoengineering, and Mining, Freiberg University of Mining and Technology, \\ 09599 Freiberg, Germany; Jaabir-Duunya.Ali@student.tu-freiberg.de \\ 3 Department of Chemical and Biological Engineering, University of Idaho, Moscow, ID 83844, USA; \\ awchild@uidaho.edu (A.W.C.); jgmoberly@uidaho.edu (J.G.M.) \\ 4 Department of Fish and Wildlife Sciences, University of Idaho, Moscow, ID 83844, USA; \\ fwilhelm@uidaho.edu \\ * Correspondence: jlangman@uidaho.edu
}

Received: 8 August 2020; Accepted: 23 September 2020; Published: 25 September 2020

\begin{abstract}
The oxidation state of sulfur [S] is a primary control on mobility of metals in sediments impacted by legacy mining practices. Coeur d'Alene Lake of northern Idaho, USA, has been impacted by upstream legacy mining practices that deposited an estimated $75 \mathrm{Mt}$ of metal(loid)- and S-rich sediments into the lake. Future lake conditions are expected to include algal blooms, which may alter $S$ and metal remobilization during the seasonal euxinic environment. Cores of the lake sediments were exposed to anoxic and anoxic + algal detritus conditions for eight weeks at $4.5^{\circ} \mathrm{C}$ through introduction of a $\mathrm{N}_{2}$ atmosphere and addition of algal detritus. At a location $2.5 \mathrm{~cm}$ below the sediment-water interface, anoxic conditions promoted a shift in S species to continually larger concentrations of reduced species and an associated shift in the bonding environment reflective of increased S-metal bonds. Anoxic + algal detritus conditions suppressed the increasing trend of reduced $\mathrm{S}$ species and induced greater release of $\mathrm{Mn}$ compared to the anoxic-only conditions but did not appear to enhance the release of As, Cd, or Fe. The addition of algal detritus to the sediment-water interface of these Feand S-rich sediments enhanced mobilization of Mn likely because of dissimilatory metal reduction where the anaerobic oxidation of the algal detritus stimulated Mn reduction. Results of the study indicate that future metal release from the lake sediments will be altered with the likely deposition of algal detritus, but the effect may not enhance the release of acutely toxic metals, such as As or Cd, or substantially impact Fe cycling in the sediments.
\end{abstract}

Keywords: mining-impacted lake; metal contamination; lakebed sediments; sulfur reduction and speciation; sulfur bonding environment; synchrotron X-ray absorption spectroscopy

\section{Introduction}

Legacy mining practices have resulted in extensive contamination through the release of sulfur [S] and toxic metals into aquatic ecosystems, which can negatively influence the health of human and wildlife populations for decades to centuries [1-5]. Coeur d'Alene Lake (Lake) of northern Idaho, USA, is located in the Coeur d'Alene River Basin (Basin) and downgradient of the lead-zinc-silver Coeur $\mathrm{d}^{\prime}$ Alene Mining District (District) (Figure 1). Legacy mining practices allowed the formation of acid 
rock drainage (ARD) and hydrologic transport of tailings and waste rock. These processes resulted in the deposition of an estimated $75 \mathrm{Mt}$ of metal(loid)- and S-rich sediments-Including 470,000 $\mathrm{t}$ of lead [Pb] and substantial masses of arsenic [As], cadmium [Cd], iron [Fe], manganese [Mn], zinc [Zn]-In the Lake over the past 100+ years [6-9]. The highest concentrations of metals in the Lake sediments are near the outlet of the Coeur d'Alene River (River) in the central part of the Lake (Figure 1), and lesser concentrations are present in the southern and northern parts of the Lake [7]. Seasonal changes in environmental conditions at the sediment-water interface (SWI) can remobilize $S$ and metals that may be transported into the Lake water column [10-20]. The Lake undergoes seasonal thermal stratification $[20,21]$ that induces changes in reduction-oxidation (redox) conditions at the SWI [22,23] where redox-sensitive As, Fe, Mn, and associated S are concentrated at an oxic-anoxic interface in this seasonally euxinic environment [24]. The strength and persistence of potential contaminant-mobilizing conditions, such as changes in redox conditions and organic matter content, determine the impact to seasonal water quality.

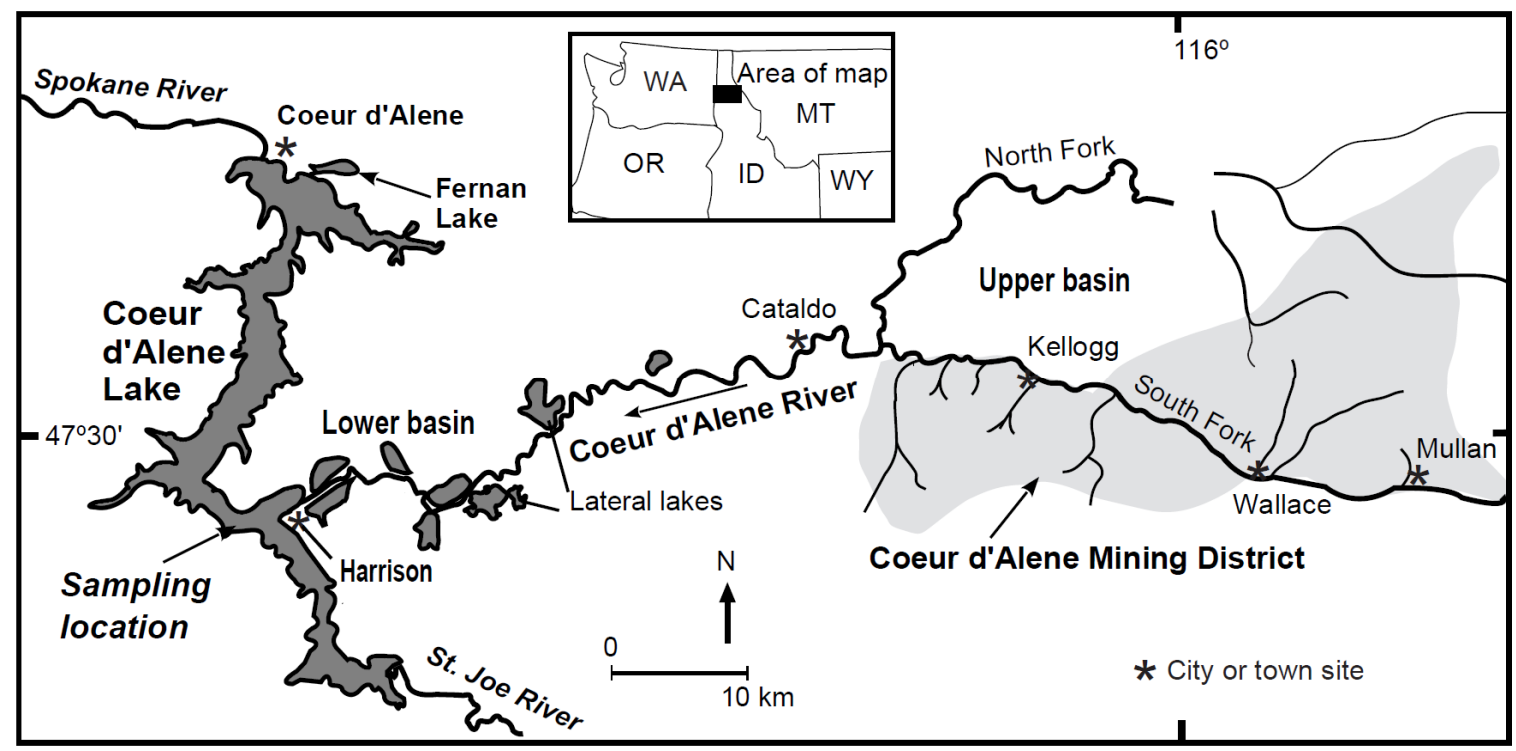

Figure 1. Coeur d'Alene Lake, River, and Mining District (Silver Valley) in northern Idaho, USA.

Historically, transport of $\mathrm{Zn}$ into the Lake has suppressed algal growth [25,26], which should be increasing because of an increasing input of phosphorus [P] [20,24,25,27,28]. Current seasonal conditions at the SWI have resulted in limited remobilization of $S$ and metals [7,8,22,29-32]. Yet, there is a growing concern of increased $S$ and metal remobilization because of an expected decrease in $\mathrm{Zn}$ inputs from remediation activities and increasing $\mathrm{P}$ inputs, which likely will produce future algal blooms similar to eutrophic and mesotrophic lakes in the region [33]. If algal blooms occur, a substantial increase in organic matter as algal detritus would be deposited at the SWI, which may alter the seasonal redox conditions that occur with thermal stratification (summer into fall) and subsequent turnover (fall). A change to the seasonal cycle of redox conditions and associated microbial communities can influence the speciation of $S$ and influence the remobilization or retention of metals [10,14,15,34-40]. The goal of this study was to evaluate the alteration of sediment $S$ species, changes to the $S$ bonding environment (local bond configuration), and the influence of $S$ redox changes on metal release under anoxic and anoxic + algal detritus conditions. These two experimental conditions are representative of current anoxia from thermal stratification and potential future conditions of anoxia and deposition of algal detritus to the SWI interface. Results of this manuscript are part of a larger study examining the Lake sediment environment, including metal release, microbial community dynamics, and nutrient inputs.

Redox-sensitive $S$ and Fe have been identified as controls on metal mobility in the contaminated sediments of the Basin, including the lateral lakes of the lower Basin (Figure 1) [17,22,32,41,42]. 
The seasonal variation in the smaller, shallower, and more productive lateral lakes and select areas of the Lake cause a cycling of sediment $S$ and metals between soluble and insoluble phases $[7,11,17,27,30$, 43-45]. Increased productivity of the Lake and deposition of algal detritus may strengthen and extend the seasonal shift to reducing conditions during the summer-to-fall thermal stratification. Alteration of redox conditions will influence the seasonal evolution of $S$ species and the mobility/immobility of the associated metals, which also will be influenced by other remobilization/retention influences, such as $\mathrm{pH}$, clays, Fe (oxyhydr)oxides, and low molecular weight organic acids [10,14,15,46-48]. Increases in $S$ reduction would allow for greater scavenging of metals (authigenic metal sulfide formation), although the greater presence of organic acids may provide substrates for metal complex formation and increased metal mobility [49-53]. To understand metal mobility or retention in these mining-impacted and euxinic environments, it is necessary to understand potential changes to $\mathrm{S}$ speciation and the associated bonding environment.

\section{Study Area, Materials, and Methods}

The Basin is bounded by the Coeur d'Alene Mountains, which are part of the Bitterroot Range of the Northern Rocky Mountains. The Coeur d'Alene Mountains are composed of quartzite and argillite of the Mesoproterozoic Belt Supergroup, which contain the ore-bearing formations that have been mined since the 1880s. The District's ore primarily consists of argentiferous galena [PbS] and sphalerite $[(\mathrm{Zn}, \mathrm{Fe}) \mathrm{S}]$ with associated carbonate zones consisting primarily of siderite $\left[\mathrm{FeCO} \mathrm{C}_{3}\right]$ and ankerite $\left[\mathrm{Ca}(\mathrm{Fe}, \mathrm{Mg}, \mathrm{Mn})\left(\mathrm{CO}_{3}\right)_{2}\right][34,35,54]$. From mining of this ore, it is estimated that $56 \mathrm{Mt}$ of processed tailings containing 900,000 $\mathrm{t}$ of $\mathrm{Pb}$ and 700,000 $\mathrm{t}$ of $\mathrm{Zn}$-along with various amounts of As, $\mathrm{Cd}, \mathrm{Fe}, \mathrm{Mn}$, and S-were discharged into the floodplain of the Coeur d'Alene River (River) and its tributaries [55]. Additionally, an unknown amount of unprocessed waste rock was disposed of in the floodplains. Transport of the disposed tailings and waste rock by high streamflows distributed the waste rock and tailings throughout the floodplain of the Basin and into the Lake $[16,54,56,57]$. Furthermore, ARD formed in abandoned mines, waste rock, and contaminated sediments where carbonate minerals were insufficient to buffer acid production $[9,34,58]$. The Lake continues to see fluctuations of $S$ and metal concentrations in the water column, partially from continued loading of $S$ and metals from the River [57] and partially from release of $S$ and metals from sediments during seasonal shifts in environmental conditions [20].

\subsection{Study Design}

This study was designed to replicate SWI conditions during a seasonal shift to anoxic conditions. Sediment cores were collected by boat in Aberdeen Lodge Bay (Figure 1, depth $\approx 15 \mathrm{~m}$ ) in the central portion of the Lake across from the discharge of the River. Two sampling periods-mid-October and mid-November-were used to collect initial cores (October) for testing of sample collection and examination of sediment physical and chemical characteristics and laboratory cores (November) for replicating anoxic (control) and anoxic + algal detritus (treatment) conditions. It was assumed these fall sampling periods would be after holomixis and reoxygenation of the water column and upper sediments. The laboratory experiments were designed for control and treatment cores to be placed in anaerobic conditions (continuous $\mathrm{N}_{2}$ atmosphere), from which a control and treatment core were removed and analyzed every two weeks over an eight-week period. Upon removal from the experiment, 1-cm sediment layers centered at $2.5 \mathrm{~cm}$ and $12.5 \mathrm{~cm}$ below the SWI were collected for X-ray absorption spectroscopy (XAS) to examine $S$ species distribution and bonding environment. Porewater was separated from the sediment samples by centrifugation (3750 RCF (relative centrifugal force) for $15 \mathrm{~min}$ ) and analyzed for $\mathrm{pH}$ and redox potential (ORP) and subsampled for analysis of dissolved (0.45- $\mu \mathrm{m}$ filtered) As, Cd, Fe, and Mn by inductively coupled plasma mass spectrometry and dissolved sulfate $\left[\mathrm{SO}_{4}\right]$ by ion chromatography at the University of Idaho Analytical Sciences Laboratory (ASL). The sediment samples were homogenized, dehydrated (lyophilized for $24 \mathrm{~h}$ ), and preserved at $-80^{\circ} \mathrm{C}$. The $2.5-\mathrm{cm}$ sample location represents the near SWI environment where 
redox-sensitive elements have concentrated [24], and the 12.5-cm sample location represents a possible restricted zone because of low permeability in these silt-clay dominated sediments near a volcanic ash layer. This deeper zone was selected for analysis to compare depth penetration of environmental changes that could influence $S$ speciation. Deeper sample locations were not considered because of the presence of a volcanic ash layer (Mount St. Helens 1980 [7,8]) about $15 \mathrm{~cm}$ below the SWI that restricts permeability and acts as a metal sorbing substrate.

\subsection{Sediment Core Collection}

Disinfected (70\% EtOH, 30\% ultrapure water), polyvinyl chloride (PVC), core barrels (5.2-cm ID $\times$ 61-cm L) were kept in a positive $\mathrm{N}_{2}$ atmosphere for $48 \mathrm{~h}$ prior to sample collection. The barrels were fitted to a Kajak-Brinkhurst gravity corer to obtain sediment cores of $40 \pm 1 \mathrm{~cm}$ with free fall from $1 \mathrm{~m}$ below the Lake surface (Figure 2). Immediately after core collection, overlying water was removed by siphoning to minimize disturbance of the SWI during transport. The cores were capped, vented with $0.20-\mu \mathrm{m}$ filters, flushed with $\mathrm{N}_{2}$, and stored upright under a $\mathrm{N}_{2}$ atmosphere in custom-made, gas-tight containers (Figure 2) for transport to the University of Idaho Lake Social Ecological Systems (LaSES) Laboratory in Coeur d'Alene, Idaho. Lake water was collected $1 \mathrm{~m}$ above the SWI using a disinfected, 2-L, Van Dorn sampler. Upon arrival at the LaSES Laboratory, core containers were checked for positive pressure $\mathrm{N}_{2}$ atmosphere and stored in the dark at $4.5 \pm 0.4{ }^{\circ} \mathrm{C}$.

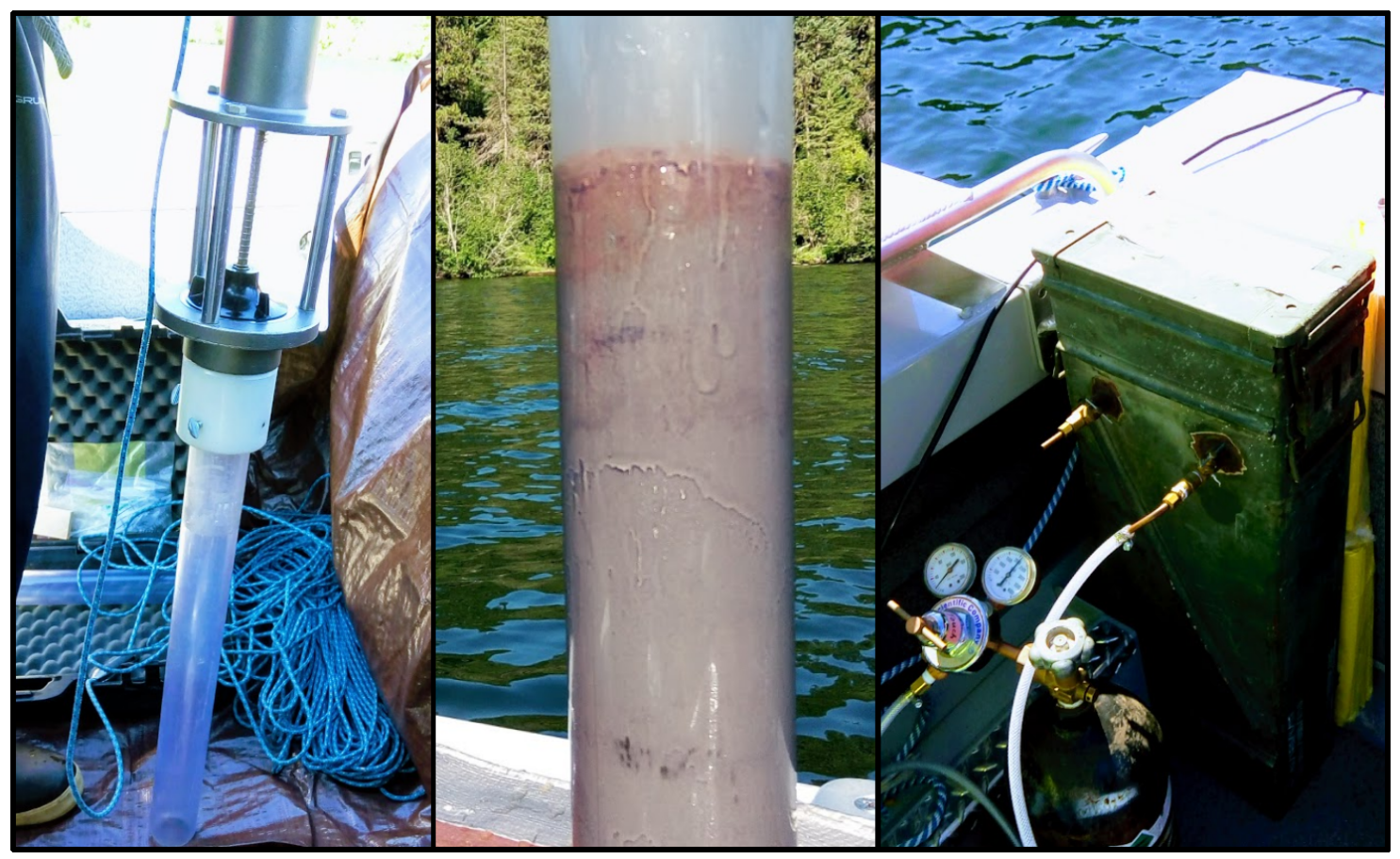

Figure 2. Kajak-Brinkhurst gravity corer, core sample, and atmospherically-sealed core container with $\mathrm{N}_{2}$ purge.

\subsection{Algal Detritus}

An adjoining and unimpacted eutrophic lake (Fernan Lake, Figure 1) was selected for collection of algae for simulating deposition of algal detritus to the SWI of the collected cores. Algae were collected from Fernan Lake by pumping surface water through an $80-\mu \mathrm{m}$ mesh net. The algae were subsequently separated from remaining water by centrifugation (3750 RCF for $15 \mathrm{~min}$ ), frozen, lyophilized, and homogenized. A slurry of algal detritus ( $~ 0.25 \mathrm{~g}$ of dry algae and $25 \mathrm{~mL}$ of lake water) was added to half of the cores along with $325 \mathrm{~mL}$ of Lake water (about $4 \mathrm{~cm}$ of head height in the core barrel) to all cores. The amount of algal detritus was based on previous sediment analyses of mesotrophic and eutrophic lakes in the region [33]. After input of the water or slurry + water, the cores were recapped, 
vented, flushed with $\mathrm{N}_{2}$, and stored at $4.5 \pm 0.4{ }^{\circ} \mathrm{C}$ upright in the dark under a $\mathrm{N}_{2}$ atmosphere in the gas-tight containers to begin the 8 -week incubation period.

\subsection{Sediment Profile Characterization}

A core from the October sample collection was sampled at the midpoint of 5-cm intervals (2.5, $7.5,12.5$, etc.) for physical and chemical characterization of the sediment profile. Core sediment characterization was performed at ASL according to quality control and assurance protocols of the North American Proficiency Testing Program. Particle size distribution was determined by hydrometer [59]. Ammonia (as $\mathrm{NH}_{3}-\mathrm{N}$ ), nitrate (as $\mathrm{NO}_{3}-\mathrm{N}$ ), phosphorus $\mathrm{P}$, and organic matter $(\mathrm{OM})$ concentrations were determined through standard extraction methods and analyzed by flow injection analysis $\left(\mathrm{NH}_{3}\right.$ and $\mathrm{NO}_{3}$ ) or spectrophotometer $(\mathrm{P}$ and $\mathrm{OM})[60,61]$.

\subsection{X-ray Spectroscopy}

The oxidation of $\mathrm{S}$ can be described as the reversible sequence of sulfide $\left[\mathrm{S}^{2-}\right] \rightarrow$ disulfide $\left[\mathrm{S}^{1-}\right] \rightarrow$ elemental $\mathrm{S}\left[\mathrm{S}^{0}\right]$ including various polysulfides $\left[\mathrm{H}_{2} \mathrm{~S}_{\mathrm{x}}\right.$ or $\left.\mathrm{S}_{\mathrm{x}}{ }^{2-}\right] \rightarrow$ sulfite $\left[\mathrm{SO}_{3}{ }^{2-}\right]$ and thiosulfate $\left[\mathrm{S}_{2} \mathrm{O}_{3}{ }^{2-}\right]$ $\rightarrow \mathrm{SO}_{4}{ }^{2-}$. Schippers and Sand (1999) [62] and Druschel et al. (2003) [63] described the transformation of $\mathrm{S}^{2-} / \mathrm{S}^{1-}$ to $\mathrm{S}_{\mathrm{x}}{ }^{0} / \mathrm{SO}_{3}{ }^{2-} / \mathrm{S}_{2} \mathrm{O}_{3}{ }^{2-}$ prior to $\mathrm{SO}_{4}{ }^{2-}$ that has been followed by substantial exploration of the presence and development of intermediary $\mathrm{S}$ species/forms during sulfide oxidation and reduction, such as growth of oxic units with $\mathrm{O}_{2}$ incorporation, possible $\mathrm{S}^{2-}$ to $\mathrm{Sx}^{0}$ to $\mathrm{S}_{2}{ }^{2-}$ evolution, Fe and $\mathrm{S}$ oxidation preference with $\mathrm{H}_{2} \mathrm{O}$ and $\mathrm{O}_{2}$ adsorption sequences, or the greater lability of the $\mathrm{Fe}-\mathrm{S}$ bond than the S-S bond [64-66]. The identification of $\mathrm{S}_{0}$ and polysulfides and $\mathrm{S}_{2} \mathrm{O}_{3}{ }^{2-}$ and polythionates $\left[\mathrm{S}_{\mathrm{x}+2} \mathrm{O}_{6}{ }^{2-}\right]$ during oxidation led to the theory of two oxidation pathways-Polysulfide or polythionate. Absorbance spectra of partially oxidized sulfides can be difficult to separate in the intermediary $\mathrm{S}$ range (prior to full oxidation to $\mathrm{SO}_{4}$ ) because of the presence of the various $\mathrm{S}$ inorganic and organic forms and their reaction rate differences that cannot be viewed as a static product $[16,67,68]$. Although, the absorbance spectra of the range of $S$ oxidation products can be used to view the shift in $S$ species distribution and bonding environment reflective of temporal changes in sediment environmental conditions [17].

The primary goal of the experiments was the temporal evaluation of the shift in sediment $S$ species and bonding environment with inducement of anoxic conditions and influence of algal detritus. The 5-cm interval samples of the October core (no anoxia or algal detritus) were analyzed to determine the metal(loid) and $S$ characteristics of the sediment profile. An Advant'XP+ sequential X-ray fluorescence (XRF) spectrometer at Washington State University's GeoAnalytical Laboratory (Pullman, WA, USA) was used to determine element composition at each 5 -cm depth (fused beads from $5 \mathrm{~g}$ of each sediment sample). These results provided relevant information for selection of the sampling points in the experimental cores (control and treatment cores). Additionally, each 5-cm interval sample from the October core was analyzed by synchrotron XAS for discriminating $S$ species and bonding environment. These XAS results provided a framework for evaluating XAS results of the experiment samples (2.5-cm (upper) and 12.5-cm (lower) sediment depths) from the control and treatment cores.

Synchrotron XAS was performed at the 06B1-1 beamline (SXRMB) at the Canadian Light Source, Saskatoon, SK, Canada. Beamline 06B1-1 uses a Si (111) monochromator to deliver an incident beam energy of $1.7-10 \mathrm{keV}$, which is suitable to resolve $\mathrm{S}$ K-edge spectra. A broad beam $(3 \mathrm{~mm} \times 2 \mathrm{~mm})$ was used to collect fluorescence mode spectra for X-ray absorption near edge structure (XANES) and X-ray absorption fine structure (XAFS) analysis. The spectra were processed with the XAS program ATHENA [69]. K-edge energies for the reference materials were determined as the maxima of the first derivative for the absorption spectra and were shifted to the theoretical values to account for beamline flux. For quality control purposes, each environmental sample was scanned twice to determine if additional scans were needed to reduce the signal-to-noise ratio (minimization of standard deviation near the K-edge). The final spectrum was calibrated to the energy shift apparent from the applicable 
standard, and the spectrum was edge-step normalized (within a maximum $15-80 \mathrm{eV}$ normalization range) for comparison of environmental samples and reference materials.

The shift in predominant $S$ oxidation states of the sediment samples were analyzed with ATHENA's linear combination fitting (LCF) capability within a K-edge range of $-20 \mathrm{eV}$ to $+40 \mathrm{eV}$. Output of the LCF consists of the percent that each reference material contributes to the fit of the sample spectrum. The goal of the LCF analysis was not discrimination of all oxidation states present in the spectra but an evaluation of the primary oxidation states and temporal shifts with changes in redox conditions (balance of reduced and oxidized species). LCF was used to reconstruct each sample spectrum using spectra from two primary reference materials-Pyrite $\left(\mathrm{FeS}_{2}, \mathrm{~S}^{1-}\right)$ and sodium bisulfite $\left(\mathrm{NaHSO}_{3}\right.$, mixed state spectra of $\mathrm{S}^{4+}$ and $\mathrm{S}^{5+}$ similar to sulfone $\left(\mathrm{RSO}_{2} \mathrm{R}, \mathrm{S}^{4+0}\right)+$ sulfonate $\left.\left(\mathrm{R}-\mathrm{SO}_{3}, \mathrm{~S}^{5+}\right)\right)$. This mixed state form appears as a broad double peak with $\mathrm{K}$ edge energies near $+5.5\left(\mathrm{~S}^{4+}\right)$ and $+8.5\left(\mathrm{~S}^{5+}\right)$ past the $\mathrm{S}^{0} \mathrm{~K}$ edge. The $\mathrm{FeS}_{2}$ and $\mathrm{NaHSO}_{3}$ represent oxidation states that constituted the large majority of the $\mathrm{S}$ species present throughout the experiments. Additional oxidation states were evaluated through attempted fitting of inorganic and organic $S$ spectra from compounds that included oxidation states of $\mathrm{S}^{2-}$ through $\mathrm{S}^{6+}$ but were not included in the LCF because of their minimal contribution to the fit. The $\mathrm{FeS}_{2}$ reference material is representative of the reduced $\mathrm{S}$ endpoint. The $\mathrm{NaHSO}_{3}$ represents a mixed $S$ intermediary state that appears to be the $S$ oxidation endpoint for solid form $S$. Our selection of a bisulfite with mixed state spectra is not an indication of an inorganic presence but a representation of this mixed oxidation state $\mathrm{S}$ form in the intermediary range $\left(\mathrm{S}^{4+}\right.$ and $\left.\mathrm{S}^{5+}\right)$. Prior $\mathrm{S}$ species analyses of Lake sediments have indicated the presence of thiols $\left(\mathrm{S}^{2+}\right)$ and sulfone and ester- $\mathrm{SO}_{4}$ [42]. We did not detect the presence of $\mathrm{S}^{2+}$ oxidation states. Similar to Toevs et al. (2006) [42], there was minimal to no $\mathrm{S}^{2-}$ or $\mathrm{S}^{6+}$ forms in all samples collected for this study.

\section{Results}

The results of the Lake sediment analyses are presented in order of the October sediment characteristics and $\mathrm{S}$ species and bonding environment $(0$ to $50 \mathrm{~cm}$ depth) followed by results from examination of the $2.5-\mathrm{cm}$ and $12.5-\mathrm{cm}$ depth samples from control and treatment cores at week 0,2 , 4,6 , and 8 of the experiments. The results of the October core analyses provide the framework for examining the results of experiment (November) cores that were subjected to anoxic (control) or anoxic + algal detritus (treatment) conditions.

\subsection{Sediment Characteristics}

Previous coring of the Lake sediments indicated elevated levels of $\mathrm{Ag}, \mathrm{As}, \mathrm{Cd}, \mathrm{Cu}, \mathrm{Fe}, \mathrm{Hg}, \mathrm{Mn}$, $\mathrm{Pb}, \mathrm{Sb}$, and $\mathrm{Zn}[7,8]$. Total depth of contamination varied from $17 \mathrm{~cm}$ to $119 \mathrm{~cm}[8]$ indicative of the bathymetric distribution of contaminated sediments and dissolved contaminants coming from the River. Examination of the October core indicated differences in metal concentrations above and below the volcanic ash layer, which is a low permeability and sorbtive layer [70,71] that separates the older and more contaminated sediments from more recently deposited sediments (Figure 3). Substantial contaminant concentrations are present above the ash- $\mathrm{Pb}$ and $\mathrm{Zn}$ concentrations up to 2425 and 3950 ppm, respectively, along with substantial Fe (about 10 wt. \% as FeO). Greater Pb concentrations are present below the ash-Up to $14,250 \mathrm{ppm}$ of $\mathrm{Pb}$ ( $\mathrm{Zn}$ was less than the concentrations above the ash). Sulfur concentrations have shown wide variation in Lake sediments, but Toevs et al. (2006) [42] indicated a mean concentration range of 95 to $140 \mathrm{mmol} / \mathrm{kg}$ from 0 to $30 \mathrm{~cm}$ at a nearby location and increasing $S$ concentrations with depth. 

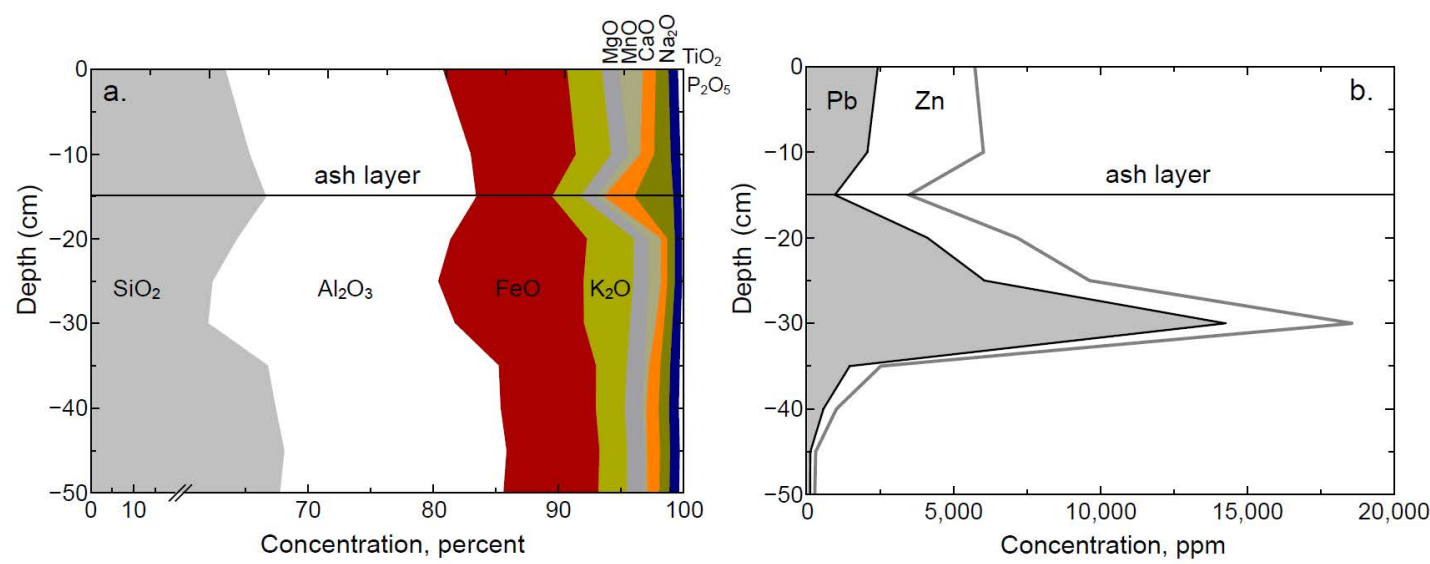

Figure 3. Cumulative area graphs of major (a) and trace element (b) concentrations for sediments collected from Aberdeen Lodge Bay in Coeur d'Alene Lake. Major elements are normalized to 100 percent. Trace element concentrations are not normalized.

The separation of the upper and lower sediments by the ash layer creates a reactive $\sim 15 \mathrm{~cm}$ of contaminated sediments below the SWI. Alteration of the redox conditions at the SWI must translate to depth in the sediments (electron transfer pathways), and the permeability of the sediments must be sufficient for transport of mobilized contaminants [72]. The Lake sediments are predominantly composed of silt and clay (silt $>52 \%$, clay $>21 \%$ ) with a smaller fraction $(<18 \%)$ of sand throughout the sediment profile (Table 1). The presence of substantial silt and clay indicates a sediment column of likely low permeability [73]. Additionally, there was a substantial presence of $\mathrm{NH}_{3}$ compared to $\mathrm{NO}_{3}$ at all depths in the October core, which is indicative of reducing conditions during this collection period. Phosphorus concentrations ranged from 15 to $27 \mu \mathrm{g} / \mathrm{g}$ and organic matter was low $(\leq 5.2 \%)$ in comparison to regional lakes [33]. Benthic flux of solutes from the sediments to the Lake is considered relatively low because of a lack of bioturbation (minimal benthic community because of contamination) and limited groundwater advection [27]. Although, solute flux across the SWI does occur as indicated by previous bromide tracer tests-Flux rates of 20 and $36 \mathrm{mg} / \mathrm{cm}^{2} / \mathrm{yr}$ [27].

Table 1. Results of sediment composition and nutrient analyses of samples from sediment cores collected from Aberdeen Lodge Bay in Coeur d'Alene Lake, October 2017.

\begin{tabular}{cccccccc}
\hline Depth (cm) & Sand & Silt & Clay & Phosphorus & Nitrate (as N) & $\begin{array}{c}\text { Ammonia } \\
\text { (as N) }\end{array}$ & $\begin{array}{c}\text { Organic } \\
\text { Matter }\end{array}$ \\
\hline Units & $\mathbf{\%}^{\mathbf{1}}$ & $\mathbf{\%}$ & $\mathbf{\%}$ & $\boldsymbol{\mu g} / \mathbf{g}^{\mathbf{2}}$ & $\boldsymbol{\mu g} / \mathbf{g}$ & $\boldsymbol{\mu g} / \mathbf{g}$ & $\mathbf{\%}$ \\
\hline 0 to 5 & 12.5 & 65.6 & 21.9 & 24 & 0.80 & 130 & 5.2 \\
5 to 10 & 13.6 & 57.6 & 28.8 & 23 & $<0.72$ & 77 & 3.3 \\
10 to 15 & 7.0 & 60.8 & 32.3 & 21 & $<0.72$ & 56 & 2.8 \\
15 to 20 & 6.1 & 59.2 & 34.7 & 20 & $<0.72$ & 69 & 3.7 \\
20 to 25 & 11.5 & 59.0 & 29.5 & 16 & 0.79 & 84 & 4.2 \\
25 to 30 & 7.9 & 66.1 & 26.0 & 15 & $<0.72$ & 130 & 4.8 \\
30 to 35 & 17.3 & 56.7 & 26.0 & 25 & $<0.72$ & 120 & 4.9 \\
35 to 40 & 11.4 & 60.4 & 28.2 & 25 & $<0.72$ & 120 & 4.2 \\
40 to 45 & 14.7 & 59.1 & 26.2 & 27 & 0.79 & 120 & 3.8 \\
45 to 50 & 16.0 & 52.5 & 31.5 & 24 & $<0.72$ & 130 & 4.6 \\
\hline \multicolumn{7}{c}{1 \%, percent; ${ }^{2} \mu \mathrm{gg} / \mathrm{g}$; microgram per gram. }
\end{tabular}

\subsection{Sediment Sulfur Speciation and Bonding Environment Characteristics}

For the October core, reduced and oxidized $S$ species were present above the ash layer $(0$ to $12.5 \mathrm{~cm})$ with a readily identifiable presence of sulfide $\left(\mathrm{S}^{1-}\right.$ at $\left.\sim 2471 \mathrm{eV}\right)$ and likely elemental $\mathrm{S}\left(\mathrm{S}^{0}\right.$ at $\left.2472 \mathrm{eV}\right)$ (Figure 4), which primarily indicates a reducing environment above the ash layer during this collection 
period. Although, mixed oxidized $S$ forms (likely mixed representation of $\mathrm{S}^{3+}(\sim 2478.5), \mathrm{S}^{4+}(\sim 2479.5)$ and $\left.\mathrm{S}^{5+}(\sim 2481 \mathrm{eV})\right)$ also were present above the ash layer but at lower concentrations as indicated by the lower peak response (Figure 4). These broad spectra peaks of oxidized $\mathrm{S}$ are representative of the intermediary products-Inorganic sulfite/thiosulfate/polythionate along with their organic counterparts of sulfone/sulfonate. The intermediary products tend to form these broad peak portions of the S spectra that are not representative of an individual oxidation state but charge densities that reflect multiple oxidation states [74]. Compared to the sediments above the ash layer, the sediments below the ash layer $(20$ to $30 \mathrm{~cm}$ ) contained greater concentrations of reduced species along with a shift towards a lower K edge $\left(<\mathrm{S}^{1-}\right)$, suggestive of non-pyritic reduced $\mathrm{S}$ forms. The sediments below the ash layer contained a greater variety of $S$ species and substantially more oxidized species with increasing depth. In these deeper sediments, there was indication of substantial accumulation of intermediary products (Figure 4). The presence of these intermediary products throughout the sediment column indicates likely partial shifts in oxidation state with seasonal changes, such as onset of reducing conditions near the surface or the upwelling of oxygenated groundwater that has been identified in the nearby lateral lakes [17]. Yet, these seasonal effects are insufficient to fully reduce or oxidize the store of $\mathrm{S}$ in any location within the sediments. Such limited reduction and oxidation (temporally and spatially) allow for the accumulation of intermediary products between the authigenic mineral form $\left(\mathrm{FeS}_{2}, \mathrm{~S}^{1-}\right)$ and fully oxidized $\mathrm{SO}_{4}$ form.

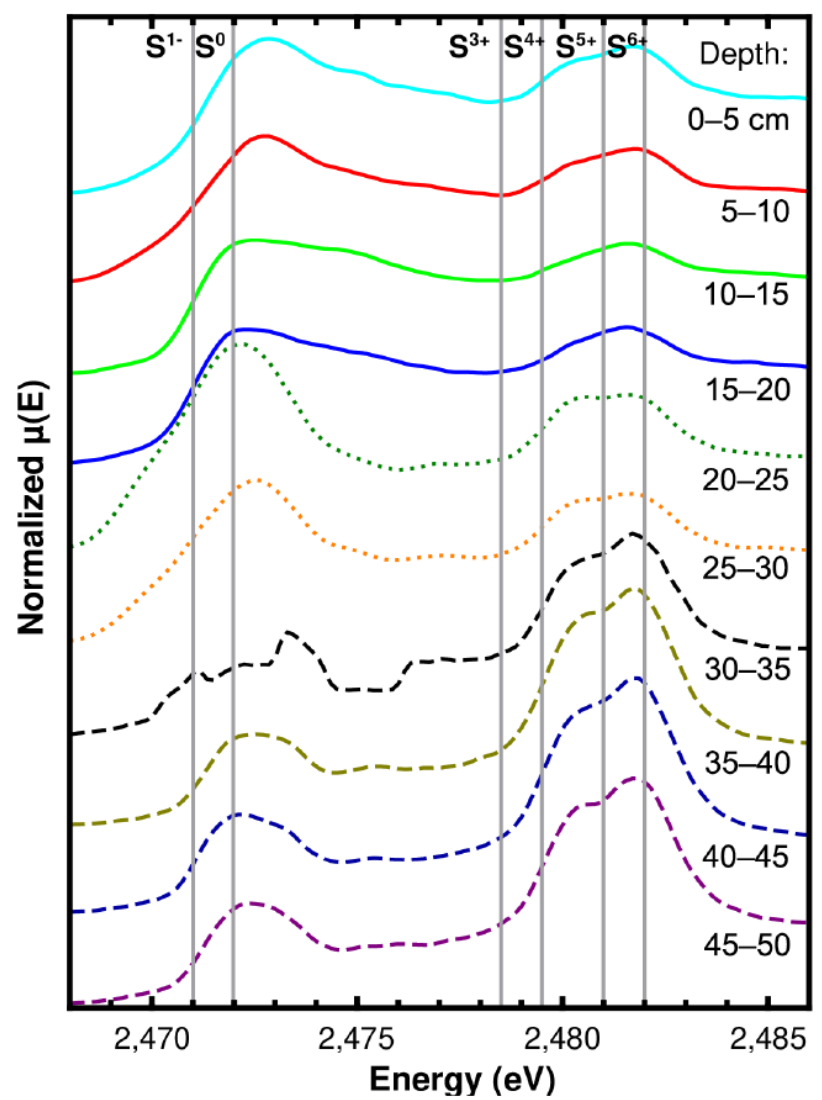

Figure 4. Sulfur absorption spectra from synchrotron XANES analysis of sediments $(0$ to $50 \mathrm{~cm})$ collected from Aberdeen Lodge Bay in Coeur d'Alene Lake, October 2017. Theoretical sulfur oxidation states are shown to illustrate their likely K-edge location (inflection point of rising limb).

Measurement of the absorption coefficient beyond the S K-edge (XAFS region) can indicate changes in coordination number, bond length, and/or local disorder of adjacent atoms [75]. The XAFS region is a reflection of dipole transitions from core to unoccupied states of the absorbing atoms (S) that reflects characteristics of adjacent (scattering) atoms [76-78]. Due to the likely inorganic and organic 
$S$ forms and seasonal environmental changes in the Lake sediments, XAFS analysis was performed to identify relative shifts in adjacent atom characteristics (e.g., bond length) through changes in 1st sphere spectra in frequency filtered (Fourier transformation with k-weight $=1$ and Hanning window (or cosine-squared taper)) for R space (Fourier transformed $\chi(R)$ in $\AA$ ) and filtered R space (q space or Fourier filtered $\chi(q)$ in $\AA-1$ ). The resulting complex number of the transformed spectra ( $R$ and $q$ space) has equivalent real and imaginary numbers equal to real $\mathrm{k}$ and imaginary $\mathrm{k}$ numbers. The real portion of the transformation represents the absolute or enveloping response of the number and disorder of scatterers and the imaginary (oscillating) part represents bond length changes between the $S$ atoms and the scatterers [79]. The real and imaginary parts complete the complex number that is reflected as a magnitude of the shell and bonding environment response to the electron wavefunction [80,81].

Non-pyritic S-S bonds are extraordinarily flexible where bond lengths can vary between 1.8 and $3.0 \AA$ [82], but pyritic S-S (and Fe-S) bonds typically are near $2.2 \AA$ [83,84]. Polysulfide S-S bonds tend to be shorter and near $2 \AA$ [85]. Additionally, C-S bonds of polysulfide compounds typically are even shorter (about $1.8 \AA$ ) [86]. S-O bonds, such as $\mathrm{SO}_{3}$ and $\mathrm{SO}_{4}$, tend to be relatively short bonds (1.4 to $1.5 \AA$ ), but a mixed state sample tends to produce a magnitude of $\chi(R)$ near $3 \AA$ because of constructive/deconstructive wave forms [87]. The magnitude of $\chi(\mathrm{R})$ for the October core is presented in Figure 5 for comparison of changes in the bonding environment with depth. The magnitude response indicates a similar bonding environment above the ash layer, a transition environment near the ash layer, and a change in the bonding environment in the deeper sediments that corresponds to the speciation differences indicated in Figure 4. The reducing conditions above the ash layer is similar in magnitude response to $\mathrm{FeS}_{2}$ and $\mathrm{S}^{0}$ standards (Figure 6), and the deeper sediments indicate more oxidized conditions similar to the magnitude response of sulfite, thiosulfate, and sulfate (Figure 6). The electron wave emitted by the absorbing $S$ atom is scattered by neighboring atoms that produces a final state wavefunction from constructive and destructive responses (Figures $5 \mathrm{~b}$ and $6 \mathrm{~b})$. The higher oscillation in the deeper sediments $(>30 \mathrm{~cm})$ likely represents constructive wave response along $\mathrm{S}-\mathrm{O}$ bonds given an expected sulfite/polythionate form (sulfite equivalent shown in Figure 6). Correspondingly, this oscillation form is minimized in the more reduced $S$ distribution, such as the lower oscillation pattern of the sediments above the ash layer where S-O bonding is less visible because of wave deconstruction with greater S-S and/or S-M bonding.
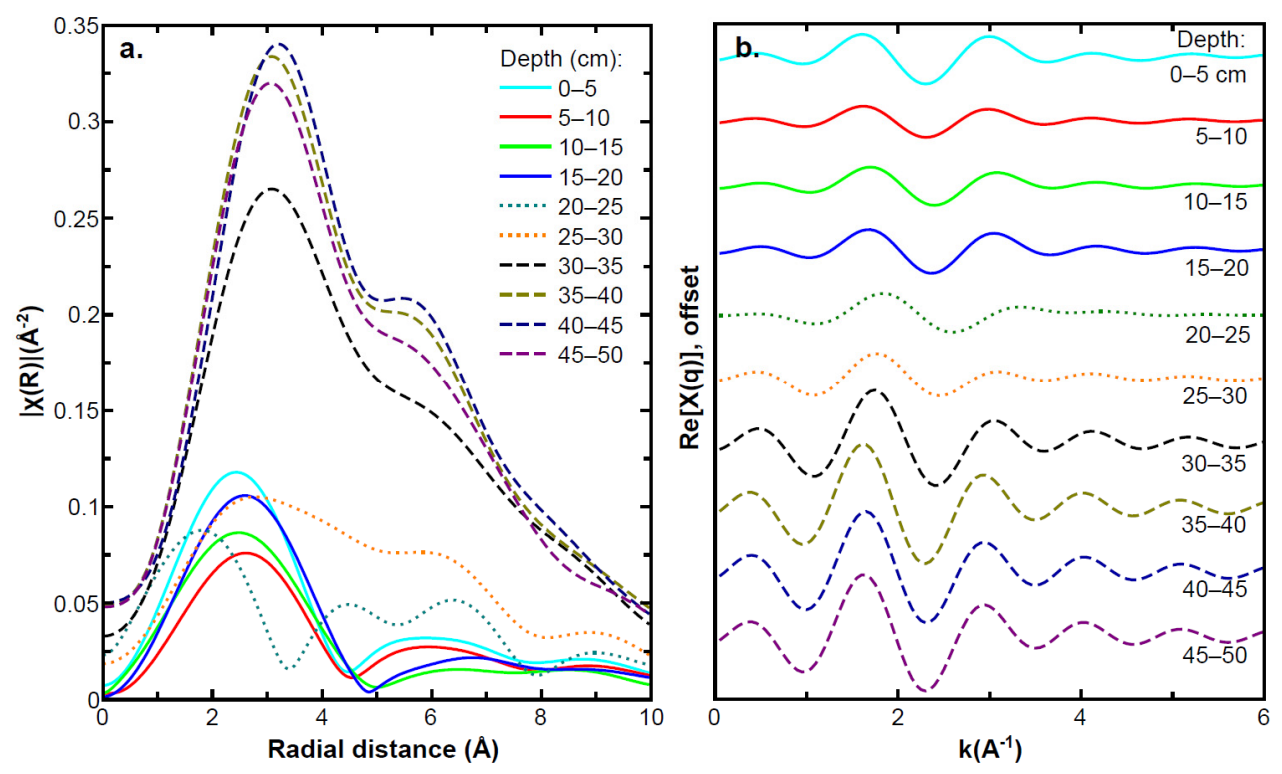

Figure 5. Sulfur XAFS spectra of 5-cm intervals of unmodified core collected from Aberdeen Lodge Bay in Coeur d'Alene Lake, October 2017: (a) radial bond length distribution after Fourier transformation $(|\chi(\mathrm{R})|)$, magnitude; $(\mathbf{b})$ Fourier filtering of $\chi(\mathrm{q})$, real portion. 

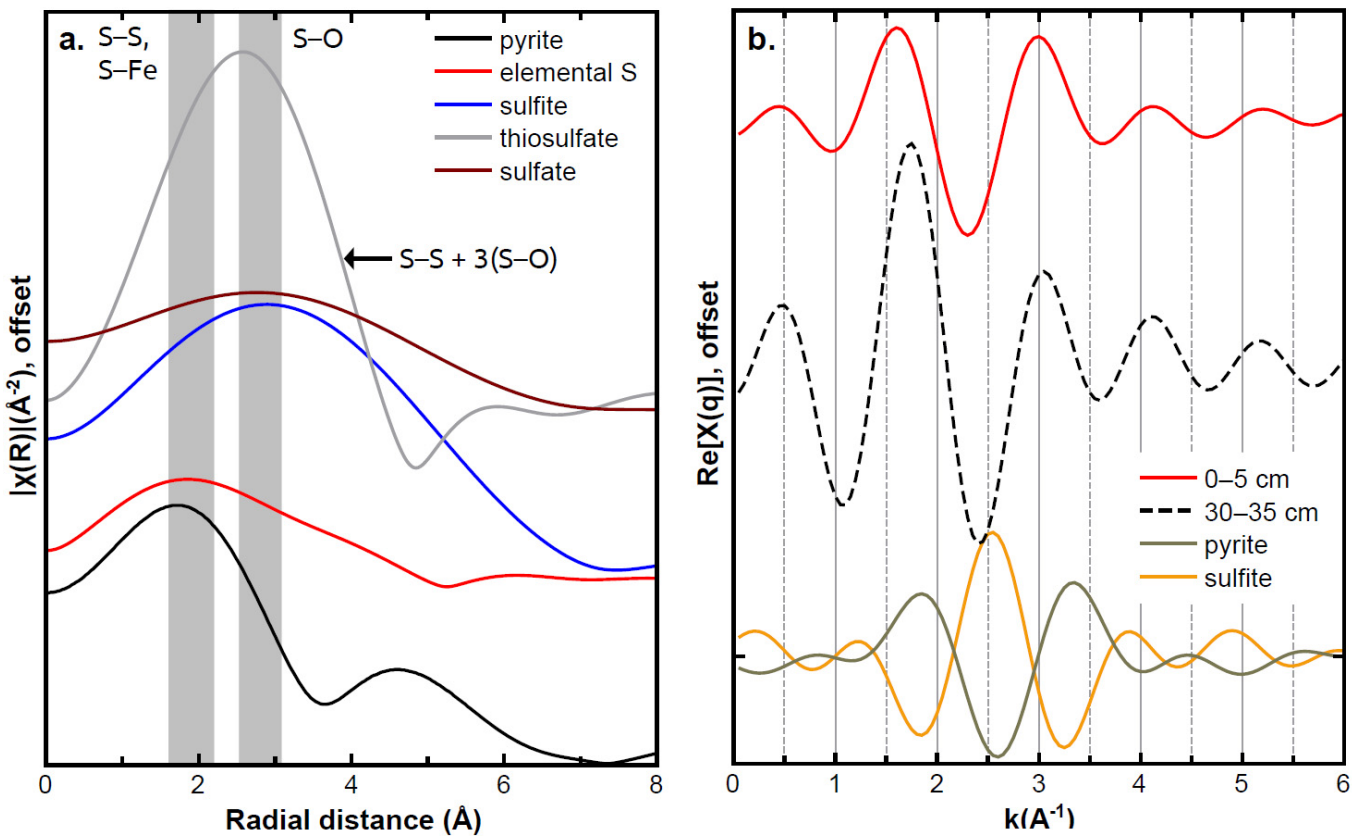

Figure 6. (a) Radial bond length distribution after Fourier transformation of sulfur standards (|x(R)|), magnitude, with common S-S, S-M, and S-O bond length ranges; and (b) Fourier filtering of $\chi(\mathrm{q})$, real portion, of pyrite and sulfite standards with the 0 to 5 and 30 to $35 \mathrm{~cm}$ spectra of the October core.

\subsection{Sediment Sulfur Speciation with Induced Anoxic Conditions}

There is no continuous monitoring of the Lake SWI for indication of reoxygenation of the water column with overturning of the thermocline. Therefore, core collection periods were set according to an expected reoxygenation period (October) and post-oxygenation period (November). Porewater was not extracted from the October core. The $\mathrm{pH}$ of porewater extracted from the November cores' upper (2.5-cm depth) and lower (12.5-cm depth) sediments over the experimental time period ranged from 6.9 to 7.1 and 6.6 to 7.6 in control and treated cores, respectively. No visible trends were apparent in $\mathrm{pH}$ in either core group or between depths. The ORP of porewater in upper and lower sediments ranged from -100 to $+65 \mathrm{mV}$ and -104 to $+65 \mathrm{mV}$ in control and treated cores, respectively, with primarily reducing conditions in lower sediments and mixed conditions in upper sediments. The lowest ORP values in upper and lower sediments were recorded during week $4 . \mathrm{NO}_{3}$ and $\mathrm{PO}_{4}$ were not detected $(<0.4 \mathrm{mg} / \mathrm{L})$ in any porewater, and $\mathrm{SO}_{4}$ concentrations were low $(<10 \mathrm{mg} / \mathrm{L})$ with no visible trend.

A comparison of solid-phase $S$ speciation in the upper sediments for the October ( -4 week) and November (0 week) samples (Figure 7) indicate primarily reduced S in October and primarily oxidized $\mathrm{S}$ in November indicating that reoxygenation of the upper sediments occurred between the two sampling events. The $S$ species of the upper sediments of the control cores (anoxia) shifted towards reduced species (predominantly $\mathrm{S}^{1-}$ ) from week 0 to week 8 (Figure 7). The upper sediments of the treatment cores (anoxia + algae) indicated variable distributions of $S$ species from week 0 to week 8 . The input of algal detritus to the SWI appears to have minimized S reduction in the upper sediments that was apparent in the control cores. The low permeability of the sediments (Table 1) appears to restrict deeper penetration of the seasonal changes in redox conditions as indicated by predominant reduced $\mathrm{S}$ forms in the lower sediments for all cores (Figure 7). 

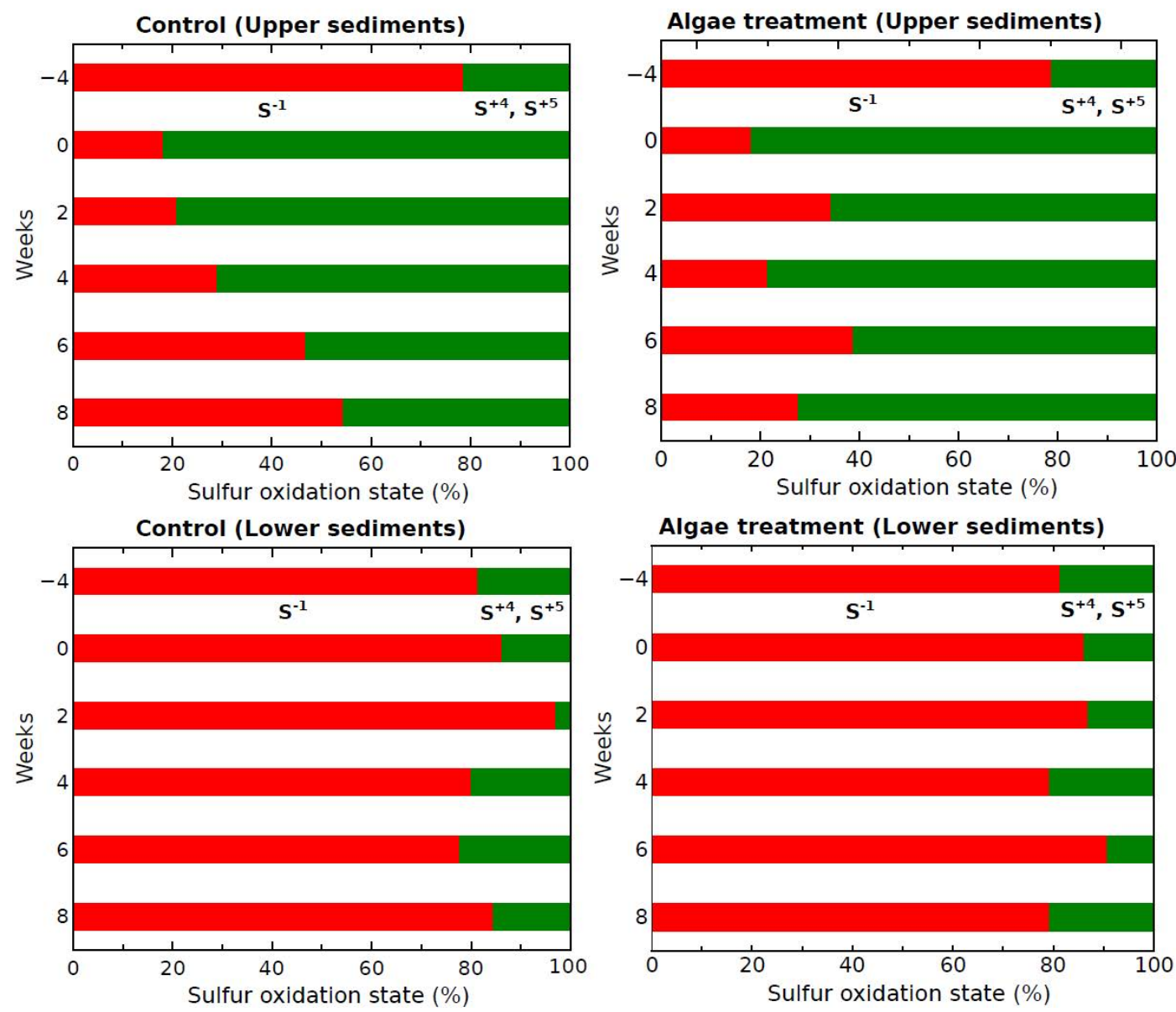

Figure 7. Distribution of the primary sulfur oxidation states $(-1$ and +4 to +5$)$ in upper and lower sediment samples of the control (anoxia) and treatment cores (anoxia + algae) over the course of the 8-week experiment.

\subsection{Upper Sediment Sulfur Bonding with Induced Anoxic Conditions}

The upper sediments of the control and treatment cores were evaluated for changes in the bonding environment given the increasing trend in reduced $S$ of the control cores and the variable redox state of $S$ in the treatment cores over the course the experiments. The bonding environment in the upper sediments of the control cores (Figure 8a) initially (week 0) appeared to indicate mixed state bond length (radial distribution) that quickly shifted (week 2) to a polythionate-type (thiosulfate of Figure 6 or greater abundance of $\mathrm{S}-\mathrm{O}$ bonds) environment that weakened in magnitude with each subsequent core (weeks 4 to 8 ). This decrease in constructive wavefunction is reflected in the week 2 to 8 scatterer response (Figure $8 \mathrm{c}$ ), which corresponds to the shift in speciation from primarily oxidized forms to greater reduced $\mathrm{S}$ during the experiment (Figure 7). This decrease in magnitude of the radial distribution for the upper sediments reflects the reduced $\mathrm{S}$ bonding of the upper sediments of the October core compared to the more oxidized environment of the deeper layers in the October core. The $\mathrm{S}$ bonding environment of the upper sediments of the treatment cores indicated a similar initial shift in bond length from week 0 to week 2 (Figure $8 \mathrm{~b}$ ), but the bonding environment of the treatment cores did not follow a similar trend in decreasing magnitude of the bond length response. Similar to the $S$ speciation variability (Figure 7) for the treatment cores, the bond lengths of $S$ and its surrounding scatters varied from week to week with an increase from week 2 to 4 , a decrease from week 4 to 6 , followed by an increase from week 6 to 8 (Figure $8 \mathrm{~b}$ ). The scatterer response and resulting wavefunction of the treated upper sediments (Figure 8d) followed a similar pattern in constructive/deconstructive responses from week to week. 

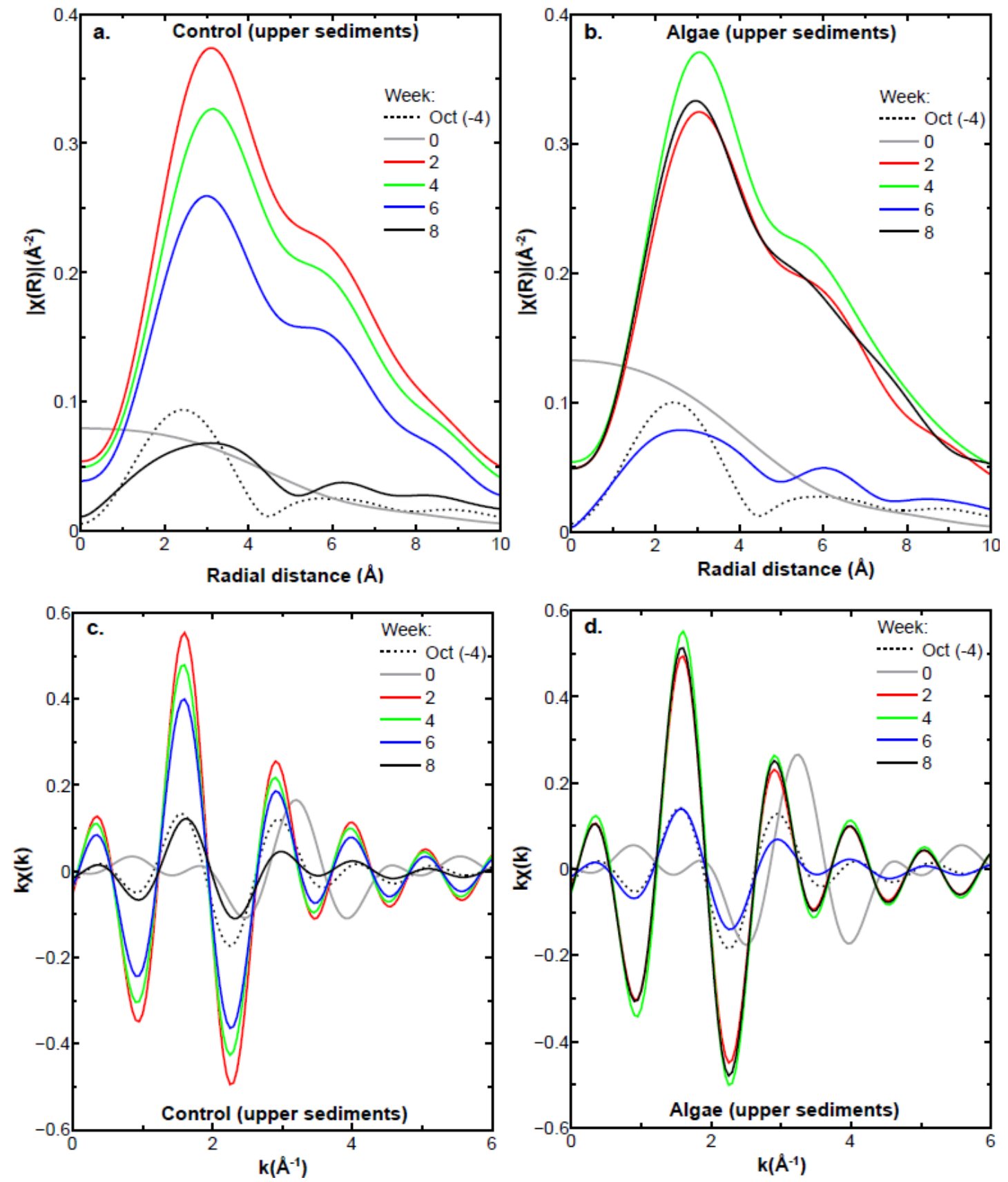

Figure 8. Sulfur XAFS spectra of control and algae-treated cores collected from Aberdeen Lodge Bay in Coeur d'Alene Lake, November 2017: (a,b) radial distribution after Fourier transformation $(|\chi(R)|)$, magnitude; (c,d) Fourier filtering of $\chi(q)$, real portion.

\subsection{Redox-Sensitive Elements in Porewater}

The anoxic and anoxic + algae conditions produced similar trends in porewater $\mathrm{As}, \mathrm{Cd}$, and $\mathrm{Fe}$ concentrations for upper and lower sediments (Figure 9). The concentration trends of each contaminant were similar at each depth under the two conditions; although, the deeper sediments produced larger concentrations of As, Cd, and Fe compared to the upper sediments. This difference in upper and lower $\mathrm{As}, \mathrm{Cd}$, and $\mathrm{Fe}$ porewater concentrations may be a result of variability of sediment metal concentrations between the two depths. Deeper sediments released greater amounts of all three metals after week 2 then plateaued with small variations in concentrations from week 4 to week 8. Upper sediment, porewater Mn was the only element to indicate a substantial difference in concentration trend between 
the anoxic and anoxic + algae conditions (Figure 9). The anoxic + algae condition produced the greatest difference $(+12,000 \mu \mathrm{g} / \mathrm{L})$ in Mn concentrations in the upper sediments during week 2, although both conditions produced relatively similar porewater Mn concentrations by the end of the experiments.
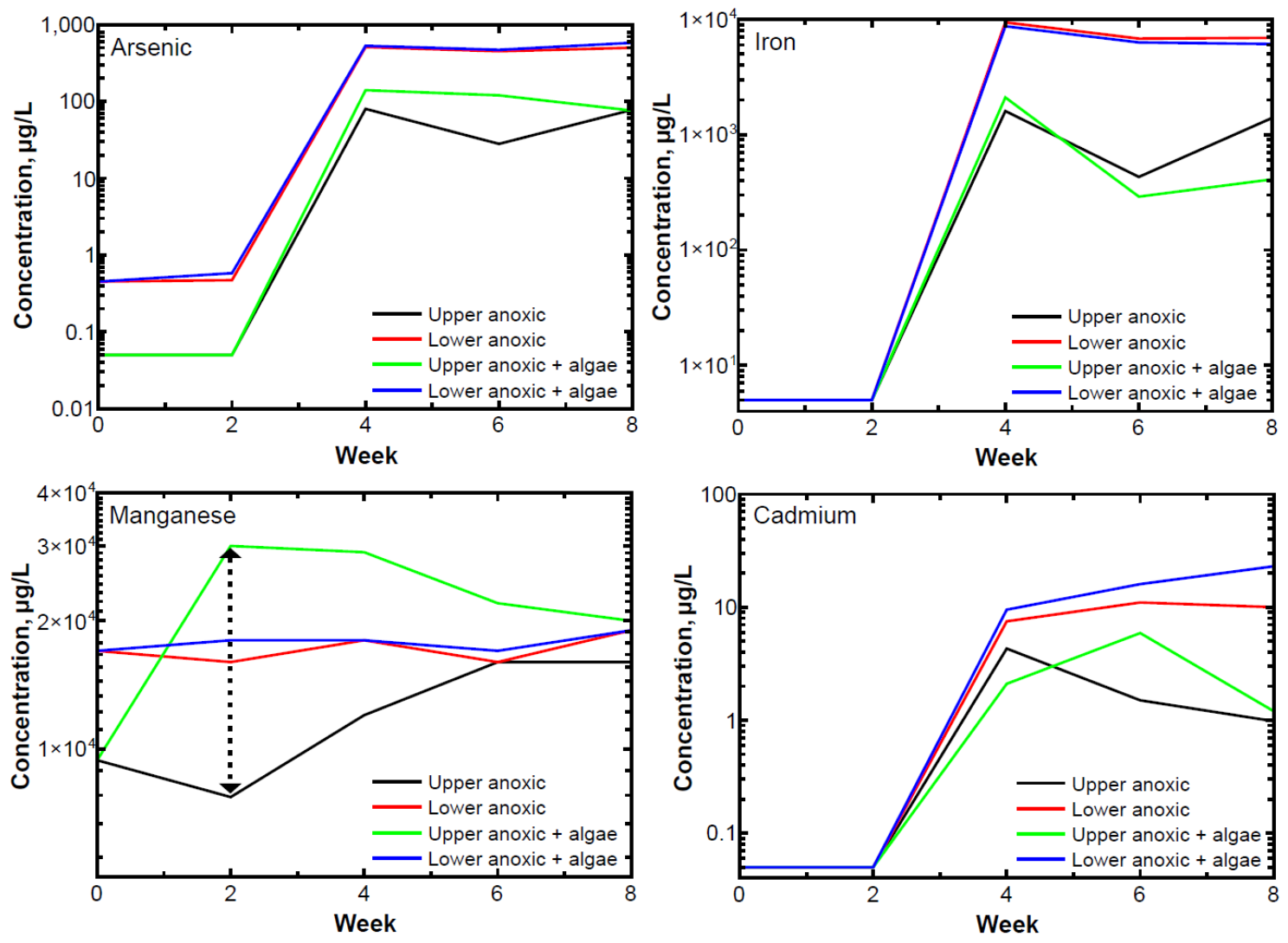

Figure 9. Metal(loid) concentrations in porewater extracted from the anoxic (control) and algae-treated (treatment) sediments analyzed for X-ray absorption spectroscopy.

\section{Discussion}

Anoxic conditions of the control cores produced an expected trend of increasing $S$ reduction in the upper sediments (Figure 7). The input of algae to the SWI was expected to provide a C- and $\mathrm{N}$-rich environment for further stimulation of reducing bacteria that could produce dissimilatory sulfate reduction with algae oxidation [88,89]. Dissimilatory sulfate reduction is a common process of $\mathrm{S}$ reduction in organic-rich environments that assists in overcoming the energy barrier of the $\mathrm{SO}_{4}-\mathrm{SO}_{3}$ redox couple [90]. Additionally, the temporal decay of the algae detritus should produce continually lower complex carbon forms that become available to the various microbial communities, which should further drive reduction of the redox-sensitive elements, such as As, Fe, Mn, and S [91,92]. Yet, the input of the algal detritus did not produce an enhancement of the $S$ reduction trend seen with the control cores (Figure 7).

Without a stimulation of $S$ reduction but the increased release of $\mathrm{Mn}$ with the addition of the algae, it appears that a dissimilatory metal reduction sequence became a dominant process in the upper sediments. Although, anoxic and anoxic + algae conditions produced similar trends in release of redox-sensitive As and Fe and a similar release of the non-redox-sensitive $\mathrm{Cd}$. The substantial change to $\mathrm{Mn}$ release with the anoxic + algae condition suggests dissimilatory reduction of Mn with algae decomposition but not inclusion of Fe or S in this stimulated reducing effect. Commonly, organic matter decomposition and metal reduction influence the redox reactions of Fe and $\mathrm{Mn}$ in aqueous systems when these two metals are of substantial concentration [93-95]. Bacteria-such as Clostridium, Geobacter, Aeromonas, Rhodoferax, Desulfobulbus, and Shewanella-have shown the ability to couple 
the oxidation of organic matter and reduction of $\mathrm{Fe}^{3+}$ and $\mathrm{Mn}^{5+}$. These metals become the primary electron acceptors and allow for oxidation of fatty acids and monoaromatic compounds $[95,96]$.

The coupling of the anaerobic oxidation of algal detritus and reduction of $\mathrm{Mn}$ is not unusual given the identification of microbially-driven dissimilatory metal reduction in Fe- and Mn-rich, anoxic, neutral $\mathrm{pH}$ sediment environments [97], but the lack of significant change in Fe release (no enhancing effect) to the porewater is unexpected. Fe has been identified as a primary element participating in redox processes within the Lake sediments where $\mathrm{Fe}$ (oxyhydr)oxides are reduced to $\mathrm{Fe}^{2+}$ minerals and an increase in dissolved Fe occurs [23]. Given the substantially greater remobilization of Mn early in the treated core experiments, it would be expected that additional Fe would release to the porewater. Some of this lack of Fe mobilization can be attributed to the neutral $\mathrm{pH}$ of the porewater throughout the experiments (limited Fe solubility compared to Mn [98]), but the lack of increased porewater Fe concentrations with the input of algae also is apparent in the similar release of As and Cd under anoxic and anoxic + algae conditions. Fe (oxyhydr)oxides are sorbing substrates in the Lake sediments and are considered a primary control on the mobility of contaminants, such as As and $\mathrm{Cd}$ [23,42]. Given no corresponding change in porewater $\mathrm{As}, \mathrm{Cd}$, or Fe compared to $\mathrm{Mn}$ for the anoxic + algae condition, anaerobic oxidation of the algae appears to only stimulate the reduction and increased release of $\mathrm{Mn}$.

\section{Conclusions}

Examination of the mining-contaminated sediments of Coeur d'Alene Lake indicate a metal- and sulfur-rich environment that undergoes seasonal anoxia due to thermal stratification of the water column. Replication of anoxic conditions for sediment cores collected from the lakebed produced an increasing trend in reduced sulfur species and enhanced S-M bonding in sediments near the sediment-water interface. No changes to the sulfur species distribution were observed for sediments in a deeper layer that remained a continuously reducing environment during all sampling and experimental conditions. Pairing an introduction of algal detritus to the sediment water interface with anoxic conditions suppressed any temporal trend in increased sulfur reduction and S-M bonding in sediments near the sediment-water interface and had no influence on sulfur speciation lower in the sediments. The sulfur bonding environment of the anoxic and anoxic + algal detritus conditions paralleled the $S$ speciation results indicative of increasing reduced S-S and S-M bonds with anoxic conditions and variable $S$ species and bonding environments under the anoxic + algae conditions. The influence of anoxia + algal detritus on sulfur speciation near the sediment-water interface produced a substantial increase in the early release of manganese to the sediment porewater compared to the anoxia-only condition. This dissimilatory metal reduction was the dominant redox process early in the experiments, which produced a substantial increase in the early release of manganese but did not enhance the release of arsenic, cadmium, and iron. This temporal effect from algal detritus appears to have altered microbial communities influence on early transformation of sulfur species and sulfur's influence on retention of manganese in the near surface sediments. Alteration of the species distribution subsequently altered the bonding environment and induced greater release of Mn compared to the anoxia-only condition. Overall, the input of the algae suppressed S reduction, enhanced the reduction of $\mathrm{Mn}$, and did not appear to influence the release of other redox-sensitive metals or release of non-redox-sensitive metals.

Author Contributions: Conceptualization, J.B.L., J.G.M., and F.M.W.; methodology, A.W.C., J.B.L, J.G.M., and F.M.W.; validation, J.B.L, J.G.M., F.M.W., and A.W.C.; formal analysis, J.B.L, J.G.M., F.M.W., A.W.C., and J.D.A.; investigation, J.B.L, J.G.M., F.M.W., A.W.C., and J.D.A.; writing-original draft preparation, J.B.L. and J.D.A.; writing-review and editing, J.B.L, J.G.M., F.M.W., A.W.C., and J.D.A.; supervision, J.B.L. and J.G.M.; funding acquisition, J.B.L. and J.G.M. All authors have read and agreed to the published version of the manuscript.

Funding: This project was funded in part by the National Science Foundation Research Infrastructure Improvement award managed by Idaho EPSCoR under award number IIA-1301792 and the US Geological Survey 104b program as administered through the Idaho Water Resources Research Institute (grant \#G16AP00050). Research described in this paper was performed at the Canadian Light Source (CLS), which is supported by the Canada Foundation for Innovation, Natural Sciences and Engineering Research Council of Canada, the University of Saskatchewan, the Government of Saskatchewan, Western Economic Diversification Canada, the National Research Council 
Canada, and the Canadian Institutes of Health Research. We wish to thank YongFeng Hu and Qunfeng Xiao of the Soft X-Ray Microcharacterization Beamline at CLS for all their help and guidance.

Conflicts of Interest: The authors declare no conflict of interest.

\section{References}

1. Bigham, J.M. Mineralogy of ochre deposits formed by sulfide oxidation. In Environmental Geochemistry of Sulfide Mine-Wastes; Jambor, J.L., Blowes, D.W., Eds.; Mineralogical Association of Canada: Quebec City, QC, Canada, 1994; Volume 22, pp. 103-132. ISBN 978-0-8412-2772-9.

2. Bigham, J.M.; Nordstrom, D.K. Iron and aluminum hydroxysulfates from acid sulfate waters. Rev. Mineral. Geochem. 2000, 40, 351-403. [CrossRef]

3. Dudka, S.; Adriano, D.C. Environmental impacts of metal ore mining and processing: A review. J. Environ. Qual. 1997, 26, 590. [CrossRef]

4. Moore, J.N.; Luoma, S.N. Hazardous wastes from large-scale metal extraction. A case study. Environ. Sci. Technol. 1990, 24, 1278-1285. [CrossRef]

5. Pyatt, F.B.; Grattan, J.P. Some consequences of ancient mining activities on the health of ancient and modern human populations. J. Public Health 2001, 23, 235-236. [CrossRef] [PubMed]

6. Balistrieri, L.S.; Bookstrom, A.A.; Box, S.E.; Ikramuddin, M. Drainage from Adits and Tailings Piles in the Coeur d'Alene Mining District, Idaho; Sampling, Analytical Methods and Results; US Geological Survey Open-File Report; United States Geological Survey: Reston, VA, USA, 1998; p. 19.

7. Horowitz, A.J.; Elrick, K.A.; Robbins, J.A.; Cook, R.B. A summary of the effects of mining and related activities on the sediment-trace element geochemistry of Lake Coeur d'Alene, Idaho, USA. J. Geochem. Explor. 1995, 52, 135-144. [CrossRef]

8. Horowitz, A.J.; Elrick, K.A.; Robbins, J.A.; Cook, R.B. Effect of mining and related activities on the sediment trace element geochemistry of Lake Coeur d'Alene, Idaho, USA part II: Subsurface sediments. Hydrol. Process. 1995, 9, 35-54. [CrossRef]

9. Paulson, A.J. Biogeochemical removal of $\mathrm{Zn}$ and $\mathrm{Cd}$ in the Coeur d'Alene River (Idaho, USA), downstream of a mining district. Sci. Total Environ. 2001, 278, 31-44. [CrossRef]

10. Aiken, G.R.; Hsu-Kim, H.; Ryan, J.N. Influence of dissolved organic matter on the environmental fate of metals, nanoparticles, and colloids. Environ. Sci. Technol. 2011, 45, 3196-3201. [CrossRef]

11. Haus, K.L.; Hooper, R.L.; Strumness, L.A.; Mahoney, J.B. Analysis of arsenic speciation in mine contaminated lacustrine sediment using selective sequential extraction, HR-ICPMS and TEM. Appl. Geochem. 2008, 23, 692-704. [CrossRef]

12. Hochella, M.F., Jr.; Mogk, D.W.; Ranville, J.; Allen, I.C.; Luther, G.W.; Marr, L.C.; McGrail, B.P.; Murayama, M.; Qafoku, N.P.; Rosso, K.M.; et al. Natural, incidental, and engineered nanomaterials and their impacts on the Earth system. Science 2019, 363. [CrossRef]

13. Hochella Jr, M.F.; Lower, S.K.; Maurice, P.A.; Penn, R.L.; Sahai, N.; Sparks, D.L.; Twining, B.S. Nanominerals, mineral nanoparticles, and Earth systems. Science 2008, 319, 1631-1635. [CrossRef] [PubMed]

14. Hoffmann, S.R.; Shafer, M.M.; Armstrong, D.E. Strong colloidal and dissolved organic ligands binding copper and zinc in rivers. Environ. Sci. Technol. 2007, 41, 6996-7002. [CrossRef]

15. Kretzschmar, R.; Schäfer, T. Metal retention and transport on colloidal particles in the environment. Elements 2005, 1, 205-210. [CrossRef]

16. Langman, J.; Torso, K.; Moberly, J. Seasonal and basinal influences on the formation and transport of dissolved trace metal forms in a mining-impacted riverine environment. Hydrology 2018, 5, 35. [CrossRef]

17. Langman, J.B.; Behrens, D.; Moberly, J.G. Seasonal formation and stability of dissolved metal particles in mining-impacted, lacustrine sediments. J. Contam. Hydrol. 2020, 232, 103655. [CrossRef] [PubMed]

18. Plathe, K.L.; von der Kammer, F.; Hassellöv, M.; Moore, J.N.; Murayama, M.; Hofmann, T.; Hochella, M.F., Jr. The role of nanominerals and mineral nanoparticles in the transport of toxic trace metals: Field-flow fractionation and analytical TEM analyses after nanoparticle isolation and density separation. Geochim. Cosmochim. Acta 2013, 102, 213-225. [CrossRef]

19. Wigginton, N.S.; Haus, K.L.; Jr, M.F.H. Aquatic environmental nanoparticles. J. Environ. Monit. 2007, 9, 1306-1316. [CrossRef] 
20. Wood, M.S.; Beckwith, M.A. Coeur d'Alene Lake, Idaho: Insights Gained From Limnological Studies of 1991-92 and 2004-06; United States Geological Survey: Reston, VA, USA, 2008; p. 40.

21. La Force, M.J.; Hansel, C.M.; Fendorf, S. Arsenic speciation, seasonal transformations, and Co-distribution with iron in a mine waste-influenced palustrine emergent wetland. Environ. Sci. Technol. 2000, 34, 3937-3943. [CrossRef]

22. Arora, B.; Şengör, S.S.; Spycher, N.F.; Steefel, C.I. A reactive transport benchmark on heavy metal cycling in lake sediments. Comput. Geosci. 2015, 19, 613-633. [CrossRef]

23. Cummings, D.E.; March, A.W.; Bostick, B.; Spring, S.; Caccavo, F.; Fendorf, S.; Rosenzweig, R.F. Evidence for microbial Fe(III) reduction in anoxic, mining-impacted lake sediments (Lake Coeur d'Alene, Idaho). Appl. Environ. Microbiol. 2000, 66, 154-162. [CrossRef]

24. Morra, M.J.; Carter, M.M.; Rember, W.C.; Kaste, J.M. Reconstructing the history of mining and remediation in the Coeur d'Alene, Idaho Mining District using lake sediments. Chemosphere 2015, 134, 319-327. [CrossRef] [PubMed]

25. Kuwabara, J.S.; Topping, B.R.; Woods, P.F.; Carter, J.L. Free zinc ion and dissolved orthophosphate effects on phytoplankton from Coeur d'Alene Lake, Idaho. Environ. Sci. Technol. 2007, 41, 2811-2817. [CrossRef] [PubMed]

26. Saxena, P. Harish Toxicity assessment of $\mathrm{ZnO}$ nanoparticles to freshwater microalgae Coelastrella terrestris. Environ. Sci. Pollut. Res. 2019, 26, 26991-27001. [CrossRef] [PubMed]

27. Kuwabara, J.S.; Woods, P.F.; Berelson, W.M.; Balistrieri, L.S.; Carter, J.L.; Topping, B.R.; Fend, S.V. Importance of sediment-water interactions in Coeur d'Alene Lake, Idaho, USA: Management implications. Environ. Manag. 2003, 32, 348-359. [CrossRef]

28. Woods, P.F.; Beckwith, M.A. Nutrient and Trace-Element Enrichment of COEUR d'Alene Lake, Idaho; United States Geological Survey: Reston, VA, USA, 1997; p. 93.

29. Harrington, J.M.; Fendorf, S.E.; Rosenzweig, R.F. Biotic generation of arsenic(III) in metal(loid)-contaminated freshwater lake sediments. Environ. Sci. Technol. 1998, 32, 2425-2430. [CrossRef]

30. Harrington, J.M.; LaForce, M.J.; Rember, W.C.; Fendorf, S.E.; Rosenzweig, R.F. Phase associations and mobilization of iron and trace elements in Coeur d'Alene Lake, Idaho. Environ. Sci. Technol. 1998, 32, 650-656. [CrossRef]

31. Pedersen, T.F. A comment on the future environmental status of Coeur d'Alene Lake, Idaho. Northwest Sci. 1996, 70, 179-182.

32. Şengör, S.S.; Spycher, N.F.; Ginn, T.R.; Sani, R.K.; Peyton, B. Biogeochemical reactive-diffusive transport of heavy metals in Lake Coeur d'Alene sediments. Appl. Geochem. 2007, 22, 2569-2594. [CrossRef]

33. Child, A.W.; Moore, B.C.; Vervoort, J.D.; Beutel, M.W. Bioavailability and uptake of smelter emissions in freshwater zooplankton in northeastern Washington, USA lakes using $\mathrm{Pb}$ isotope analysis and trace metal concentrations. Environ. Pollut. 2018, 238, 348-358. [CrossRef]

34. Balistrieri, L.S.; Box, S.E.; Tonkin, J.W. Modeling precipitation and sorption of elements during mixing of river water and porewater in the Coeur d'Alene River Basin. Environ. Sci. Technol. 2003, 37, 4694-4701. [CrossRef]

35. Balistrieri, L.S.; Blank, R.G. Dissolved and labile concentrations of $\mathrm{Cd}, \mathrm{Cu}, \mathrm{Pb}$, and $\mathrm{Zn}$ in the South Fork Coeur d'Alene River, Idaho: Comparisons among chemical equilibrium models and implications for biotic ligand models. Appl. Geochem. 2008, 23, 3355-3371. [CrossRef]

36. Dockrey, J.W.; Lindsay, M.B.J.; Mayer, K.U.; Beckie, R.D.; Norlund, K.L.I.; Warren, L.A.; Southam, G. Acidic microenvironments in waste rock characterized by neutral drainage: Bacteria-mineral interactions at sulfide surfaces. Minerals 2014, 4, 170-190. [CrossRef]

37. Gao, Y.; Kan, A.T.; Tomson, M.B. Critical evaluation of desorption phenomena of heavy metals from natural sediments. Environ. Sci. Technol. 2003, 37, 5566-5573. [CrossRef]

38. Rickard, D.; Luther, G.W. Chemistry of iron sulfides. Chem. Rev. 2007, 107, 514-562. [CrossRef] [PubMed]

39. Schaider, L.A.; Senn, D.B.; Estes, E.R.; Brabander, D.J.; Shine, J.P. Sources and fates of heavy metals in a mining-impacted stream: Temporal variability and the role of iron oxides. Sci. Total Environ. 2014, 490, 456-466. [CrossRef] [PubMed]

40. Schippers, A. Biogeochemistry of metal sulfide oxidation in mining environments, sediments, and soils. Geol. Soc. Am. Spec. Pap. 2004, 379, 49-62. [CrossRef] 
41. Toevs, G.; Morra, M.J.; Winowiecki, L.; Strawn, D.; Polizzotto, M.L.; Fendorf, S. Depositional influences on porewater arsenic in sediments of a mining-contaminated freshwater lake. Environ. Sci. Technol. 2008, 42, 6823-6829. [CrossRef]

42. Toevs, G.R.; Morra, M.J.; Polizzotto, M.L.; Strawn, D.G.; Bostick, B.C.; Fendorf, S. Metal(loid) diagenesis in mine-impacted sediments of Lake Coeur d'Alene, Idaho. Environ. Sci. Technol. 2006, 40, 2537-2543. [CrossRef]

43. Bostick, B.C.; Hansel, C.M.; Fendorf, S. Seasonal fluctuations in zinc speciation within a contaminated wetland. Environ. Sci. Technol. 2001, 35, 3823-3829. [CrossRef]

44. Moberly, J.; D'Imperio, S.; Parker, A.; Peyton, B. Microbial community signature in Lake Coeur d'Alene: Association of environmental variables and toxic heavy metal phases. Appl. Geochem. 2016, 66, 174-183. [CrossRef]

45. Moberly, J.G.; Borch, T.; Sani, R.K.; Spycher, N.F.; Şengör, S.S.; Ginn, T.R.; Peyton, B.M. Heavy metal-mineral associations in Coeur d'Alene River sediments: A synchrotron-based analysis. Water. Air. Soil Pollut. 2008, 201, 195-208. [CrossRef]

46. Boujelben, N.; Bouzid, J.; Elouear, Z. Adsorption of nickel and copper onto natural iron oxide-coated sand from aqueous solutions: Study in single and binary systems. J. Hazard. Mater. 2009, 163, 376-382. [CrossRef] [PubMed]

47. Cornell, R.M. Simultaneous incorporation of $\mathrm{Mn}, \mathrm{Ni}$ and $\mathrm{Co}$ in the goethite (alpha -FeOOH) structure. Clay Miner. 1991, 26, 427-430. [CrossRef]

48. Galán, E.; Gómez-Ariza, J.L.; González, I.; Fernández-Caliani, J.C.; Morales, E.; Giráldez, I. Heavy metal partitioning in river sediments severely polluted by acid mine drainage in the Iberian Pyrite Belt. Appl. Geochem. 2003, 18, 409-421. [CrossRef]

49. Chen, K.L.; Elimelech, M. Influence of humic acid on the aggregation kinetics of fullerene (C60) nanoparticles in monovalent and divalent electrolyte solutions. J. Colloid Interface Sci. 2007, 309, 126-134. [CrossRef] [PubMed]

50. Filella, M.; Buffle, J. Factors controlling the stability of submicron colloids in natural waters. In Colloids in the Aquatic Environment; Tadros, T.F., Gregory, J., Eds.; Elsevier: Oxford, UK, 1993; pp. 255-273. ISBN 978-1-85861-038-2.

51. Hyung, H.; Fortner, J.D.; Hughes, J.B.; Kim, J.-H. Natural organic matter stabilizes carbon nanotubes in the aqueous phase. Environ. Sci. Technol. 2007, 41, 179-184. [CrossRef]

52. Keller, A.A.; Wang, H.; Zhou, D.; Lenihan, H.S.; Cherr, G.; Cardinale, B.J.; Miller, R.; Ji, Z. Stability and aggregation of metal oxide nanoparticles in natural aqueous matrices. Environ. Sci. Technol. 2010, 44, 1962-1967. [CrossRef]

53. Pizarro, J.; Belzile, N.; Filella, M.; Leppard, G.G.; Negre, J.-C.; Perret, D.; Buffle, J. Coagulation/sedimentation of submicron iron particles in a eutrophic lake. Water Res. 1995, 29, 617-632. [CrossRef]

54. National Research Council. Superfund and Mining Megasites: Lessons from the Coeur d'Alene River Basin; The National Academies of Sciences, Engineering, Medicine: Washington, DC, USA, 2005; p. 484.

55. Long, K.R. Production and Disposal of Mill Tailings in the Coeur d'Alene Mining Region, Shoshone County, Idaho; Preliminary Estimates; United States Geological Survey: Reston, VA, USA, 1998.

56. Balistrieri, L.S.; Box, S.E.; Bookstrom, A.A.; Hooper, R.L.; Mahoney, J.B. Impacts of Historical Mining in the Coeur d'Alene River Basin; Bulletin; United States Geological Survey: Reston, VA, USA, 2010.

57. Clark, G.M.; Mebane, C.A. Sources, Transport, and Trends for Selected Trace Metals and Nutrients in the Coeur d'Alene and Spokane River Basins, Northern Idaho, 1990-2013; United States Geological Survey: Reston, VA, USA, 2014; p. 62.

58. Tonkin, J.W.; Balistrieri, L.S.; Murray, J.W. Modeling metal removal onto natural particles formed during mixing of acid rock drainage with ambient surface water. Environ. Sci. Technol. 2002, 36, 484-492. [CrossRef]

59. Holliday, V.T. Methods of soil analysis, part 1, physical and mineralogical methods. Geoarchaeology 1990, 5, 87-89. [CrossRef]

60. Gavlak, R.; Horneck, D.; Miller, R.O. Soil, Plant, and Water Reference Methods for the Western Region. In Proceedings of the WERA-103 Technical Committee, 3rd ed.; Oregon State University: Corvallis, OR, USA, 2005; Volume WREP 125.

61. Sims, J.R.; Haby, V.A. Simplified colorimetric determination of soil organic matter. Soil Sci. 1971, 101, $137-141$. [CrossRef] 
62. Schippers, A.; Sand, W. Bacterial leaching of metal sulfides proceeds by two indirect mechanisms via thiosulfate or via polysulfides and sulfur. Appl. Environ. Microbiol. 1999, 65, 319-321. [CrossRef]

63. Druschel, G.K.; Hamers, R.J.; Banfield, J.F. Kinetics and mechanism of polythionate oxidation to sulfate at low $\mathrm{pH}$ by $\mathrm{O}_{2}$ and $\mathrm{Fe}^{3+}$. Geochim. Cosmochim. Acta 2003, 67, 4457-4469. [CrossRef]

64. Li, Y.; Chen, J.; Chen, Y.; Zhao, C.; Zhang, Y.; Ke, B. Interactions of oxygen and water molecules with pyrite surface: A new insight. Langmuir 2018, 34, 1941-1952. [CrossRef]

65. Terranova, U.; Mitchell, C.; Sankar, M.; Morgan, D.; de Leeuw, N.H. Initial oxygen incorporation in the prismatic surfaces of troilite FeS. J. Phys. Chem. C 2018, 122, 12810-12818. [CrossRef]

66. Zhang, T.; Wang, Y.; Hu, Y.; Wang, Z.; Chen, J.; Niu, X.; Li, Y.; Gong, X. HO selective cleavage FeS bond for $\mathrm{FeS}_{2}$ electrolysis in alkaline solution. Electrochimica Acta 2019, 306, 327-338. [CrossRef]

67. Findlay, A.J.; Kamyshny, A. Turnover rates of intermediate sulfur species $\left(\mathrm{S}_{\mathrm{x}}{ }^{2-}, \mathrm{S}^{0}, \mathrm{~S}_{2} \mathrm{O}_{3}{ }^{2-}, \mathrm{S}_{4} \mathrm{O}_{6}{ }^{2-}, \mathrm{SO}_{3}{ }^{2-}\right)$ in anoxic freshwater and sediments. Front. Microbiol. 2017, 8. [CrossRef]

68. Langman, J.B.; Blowes, D.W.; Sinclair, S.A.; Krentz, A.; Amos, R.T.; Smith, L.J.D.; Pham, H.N.; Sego, D.C.; Smith, L. Early evolution of weathering and sulfide depletion of a low-sulfur, granitic, waste rock in an Arctic climate: A laboratory and field site comparison. J. Geochem. Explor. 2015, 156, 61-71. [CrossRef]

69. Ravel, B.; Newville, M. ATHENA, ARTEMIS, HEPHAESTUS: Data analysis for X-ray absorption spectroscopy using IFEFFIT. J. Synchrotron Radiat. 2005, 12, 537-541. [CrossRef]

70. Heap, M.J.; Reuschlé, T.; Farquharson, J.I.; Baud, P. Permeability of volcanic rocks to gas and water. J. Volcanol. Geotherm. Res. 2018, 354, 29-38. [CrossRef]

71. Jensen, L.C.; Becerra, J.R.; Escudey, M. Impact of physical/chemical properties of volcanic ash-derived soils on mechanisms involved during sorption of ionisable and non-ionisable herbicides. Adv. Sorpt. Process Appl. 2018. [CrossRef]

72. Huettel, M.; Røy, H.; Precht, E.; Ehrenhauss, S. Hydrodynamical impact on biogeochemical processes in aquatic sediments. In The Interactions between Sediments and Water; Kronvang, B., Ed.; Springer: Dordrecht, The Netherlands, 2003; pp. 231-236.

73. Bryant, W.R. Permeability of clays, silty-clays and clayey-silts. Gulf Coast Assoc. Geol. Soc. Trans. 2002, 52, 1069-1077.

74. Behyan, S.; Hu, Y.; Urquhart, S.G. Sulfur 1s near-edge X-ray absorption fine structure (NEXAFS) of thiol and thioether compounds. J. Chem. Phys. 2011, 134, 244304. [CrossRef] [PubMed]

75. Sham, T.K. Nanoparticles and nanowires: Synchrotron spectroscopy studies. Int. J. Nanotechnol. 2008, 5, 1194-1246. [CrossRef]

76. Alp, E.E.; Mini, S.M.; Ramanathan, M. X-ray Absorption Spectroscopy: EXAFS and XANES-A Versatile Tool to Study the Atomic and Electronic Structure of Materials; Argonne National Laboratory: Lemont, IL, USA, 1990; pp. 25-36.

77. Penner-Hahn, J.E. X-ray absorption spectroscopy. eLS 2005. [CrossRef]

78. Yang, Y.; Harmer, S.; Chen, M. Synchrotron-based XPS and NEXAFS study of surface chemical species during electrochemical oxidation of chalcopyrite. Hydrometallurgy 2015, 156, 89-98. [CrossRef]

79. Koningsberger, D.C.; Ramaker, D.E. Applications of X-ray Absorption Spectroscopy in Heterogeneous Catalysis: EXAFS, Atomic XAFS, and Delta XANES. In Handbook of Heterogeneous Catalysis; American Cancer Society: Atlanta, GA, USA, 2008; pp. 774-803. ISBN 978-3-527-61004-4.

80. Koningsberger, D.C.; Mojet, B.L.; van Dorssen, G.E.; Ramaker, D.E. XAFS spectroscopy; fundamental principles and data analysis. Top. Catal. 2000, 10, 143-155. [CrossRef]

81. Newville, M. Fundamentals of XAFS. Rev. Mineral. Geochem. 2014, 78, 33-74. [CrossRef]

82. Steudel, R. Properties of sulfur-sulfur bonds. Angew. Chem. Int. 1975, 14, 655-664. [CrossRef]

83. Dos Santos, E.C.; Lourenço, M.P.; Pettersson, L.G.M.; Duarte, H.A. Stability, structure, and electronic properties of the pyrite/arsenopyrite solid-solid interface-A DFT study. J. Phys. Chem. C 2017, 121, 8042-8051. [CrossRef]

84. Dos Santos, E.C.; de Mendonça Silva, J.C.; Duarte, H.A. Pyrite oxidation mechanism by oxygen in aqueous medium. J. Phys. Chem. C 2016, 120, 2760-2768. [CrossRef]

85. El Jaroudi, O.; Picquenard, E.; Demortier, A.; Lelieur, J.-P.; Corset, J. Polysulfide anions. 1. Structure and vibrational spectra of the S22- and S32- anions. Influence of the cations on bond length and angle. Inorg. Chem. 1999, 38, 2394-2401. [CrossRef] 
86. Nikoo, S.; Meister, P.J.; Hayward, J.J.; Gauld, J.W. An assessment of computational methods for calculating accurate structures and energies of bio-relevant polysulfur/selenium-containing compounds. Molecules 2018, 23, 3323. [CrossRef] [PubMed]

87. Hawthorne, F.C.; Krivovichev, S.V.; Burns, P.C. The crystal chemistry of sulfate minerals. Rev. Mineral. Geochem. 2000, 40, 1-112. [CrossRef]

88. Bradley, A.S.; Leavitt, W.D.; Johnston, D.T. Revisiting the dissimilatory sulfate reduction pathway. Geobiology 2011, 9, 446-457. [CrossRef]

89. Plugge, C.M.; Zhang, W.; Scholten, J.C.M.; Stams, A.J.M. Metabolic flexibility of sulfate-reducing bacteria. Front. Microbiol. 2011, 2. [CrossRef]

90. Santos, A.A.; Venceslau, S.S.; Grein, F.; Leavitt, W.D.; Dahl, C.; Johnston, D.T.; Pereira, I.A.C. A protein trisulfide couples dissimilatory sulfate reduction to energy conservation. Science 2015, 350, 1541-1545. [CrossRef]

91. Canfield, D.E. Sulfate reduction and oxic respiration in marine sediments: Implications for organic carbon preservation in euxinic environments. Deep Sea Res. Part Oceanogr. Res. Pap. 1989, 36, 121-138. [CrossRef]

92. Holmer, M.; Storkholm, P. Sulphate reduction and sulphur cycling in lake sediments: A review. Freshw. Biol. 2001, 46, 431-451. [CrossRef]

93. Lovley, D.R. Fe(III) and Mn(IV) reduction. Environ. Microbe-Met. Interact. 2000, 3-30. [CrossRef]

94. Lovley, D.R. Dissimilatory Fe(III) and Mn(IV) reduction. Microbiol. Mol. Biol. Rev. 1991, 55, $259-287$. [CrossRef]

95. Nealson, K.H.; Myers, C.R. Microbial reduction of manganese and iron: New approaches to carbon cycling. Appl. Environ. Microbiol. 1992, 58, 439-443. [CrossRef] [PubMed]

96. Bretschger, O.; Obraztsova, A.; Sturm, C.A.; Chang, I.S.; Gorby, Y.A.; Reed, S.B.; Culley, D.E.; Reardon, C.L.; Barua, S.; Romine, M.F.; et al. Current production and metal oxide reduction by shewanella oneidensis MR-1 wild type and mutants. Appl. Environ. Microbiol. 2007, 73, 7003-7012. [CrossRef]

97. Lovley, D.R.; Giovannoni, S.J.; White, D.C.; Champine, J.E.; Phillips, E.J.P.; Gorby, Y.A.; Goodwin, S. Geobacter metallireducens gen. nov. sp. nov., a microorganism capable of coupling the complete oxidation of organic compounds to the reduction of iron and other metals. Arch. Microbiol. 1993, 159, 336-344. [CrossRef] [PubMed]

98. Hem, J.D. Chemical factors that influence the availability of iron and manganese in aqueous systems. GSA Bull. 1972, 83, 443-450. [CrossRef] 